\title{
A tribute to Lawrence Rogers Blinks (1900-1989): light and algae
}

\author{
Anitra Thorhaug · Graeme Berlyn
}

Received: 23 March 2009/ Accepted: 5 May 2009/Published online: 17 June 2009

(C) Springer Science+Business Media B.V. 2009

\begin{abstract}
We honor Lawrence Rogers Blinks (19001989) in this tribute. We introduce his scientific life that started at the Harvard University, and ended at the Hopkins Marine Station of Stanford University. We discuss his pioneering contributions in the areas of ion transport in membranes and of photosynthesis, particularly of the phenomenon that became known as the Blinks Effect, later linked to the two-light and two-pigment system scheme of photosynthesis. We have drawn information from the 2006 symposium held in his honor in California, and from the extensive 2006 and 2008 recollections of Francis Haxo, one of the major coworkers of Blinks.
\end{abstract}

Keywords Action spectrum - Photosystems I and II · Algae $\cdot$ Red light $\cdot$ Blue light $\cdot$ Porphyra $\cdot$ Valonia . Nitella $\cdot$ Ulva $\cdot$ Ricinus $\cdot$ Red algae $\cdot$ Phytochrome . Monochromatic light · Chromatic transients . Photosynthetic enhancement - Carotenoids . Phycoerythrins $\cdot$ Phytochrome $\cdot$ Phycobilins . Action spectrum of photosynthesis . Stanford University Hopkins Marine Station . Harvard University · Rockefeller Institute . University of California at Santa Cruz . National Academy of Sciences · USA

This manuscript was invited and edited by Govindjee, the Founding Historical Corner Editor of Photosynthesis Research; he thanks John Raven, Anthony Larkum, Francis and Judith Haxo, Winslow Briggs and David Fork for reading this tribute and for their valuable comments. For emphasis, Francis Haxo's unpublished quotations are placed here in text boxes.

A. Thorhaug $(\bowtie) \cdot$ G. Berlyn

School of Forestry and Environmental Studies, Yale University, Greeley Laboratories, Prospect St, New Haven, CT 06511, USA e-mail: athorhaug@msn.com

\section{Introduction}

Lawrence Blinks died, after a short illness, on March 22, 1989 in Pacific Grove, California, at the age of 88. He had been working in his algal physiological laboratory on membrane phenomena until this illness. In this Introduction, we include a prologue for this Tribute. Blinks was Professor Emeritus from Stanford University, a member of the National Academy of Sciences (1955-1989), Director of Stanford's Hopkins Marine Station for 21 years (19431964),Vice President of the National Science Foundation (1955), editor of the Journal of General Physiology (19511957) and editor of the Annual Review of Plant Physiology (now Plant Biology) (1955). He started his membrane and algal work with Winthrop R.V. Osterhout (1871-1964) and Jacques Loeb (1859-1926) at Harvard University (19221926) and then worked with them at the Rockefeller Institute (1926-1931) before leaving for Stanford University (1931-1989) and before he commenced his photosynthesis research. Blinks's early membrane work laid the foundation for membrane transport in plant cells and electrical properties of membranes. He is best known in the photosynthesis community for the Haxo-Blinks oxygen electrode (Blinks and Skow 1938a, b, as modified and used in Haxo and Blinks 1950) and for the Blinks effect in a red alga Porphyra, where a green flash $(540 \mathrm{~nm})$ after red flash $(675 \mathrm{~nm})$ of light gave higher rates of oxygen exchange in contrast to a lower rate when the red flash was given after the green flash (Blinks 1957); Blinks originally hypothesized (in hindsight, wrongly-editorial comment by Govindjee) that these red-green effects were due to respiration, not photosynthesis. Following the discovery of the "red drop" in photosynthetic yield (Emerson and Lewis 1943), Emerson et al. (1957) discovered an enhancement effect in photosynthesis when two different light beams, exciting 
two different pigments, gave higher rates than the sum of photosynthesis in the two beams given separately (see Emerson and Rabinowitch 1960; Govindjee and Rabinowitch 1960). These were later explained in terms of two separate photosystems and two light reactions. Myers and French (1960) measured both the Blinks effect and the Emerson effect in the same organism, Chlorella, and concluded that both these effects were caused by the same phenomenon, photosynthetic enhancement. (Also see comments on this in the section below where Francis Haxo's recollections, as well as comments by other scientists, are cited.) Haxo and Blinks (1950) had earlier found through measuring the action spectra of a number of red algae that light absorbed by phycoerythrin was far more effective in light harvesting for photosynthesis than light absorbed in the region of chlorophyll $a$. Duysens (1952) then discovered two forms of chlorophyll $a$, one fluorescent that received excitation energy from phycoerythrin, and the other that was non-fluorescent. This non-fluorescent chlorophyll $a$, later found to be largely attached to Photosystem I, was active in oxygen evolution only in conjunction with the fluorescent forms of chlorophyll $a$ that was associated with photosystem II.

In this tribute, we also present Blinks's non-photosynthesis research contributions to science and institution building especially his substantial research contributions to membrane and ion transport. For Blinks's photosynthesis research, we have cited authoritative photosynthesis reviews by others including an extensive remembrance written for this tribute by Francis Haxo, a colleague and postdoctoral associate of Blinks during the critical action spectra measurements and pigment photosynthetic work.

Figure 1 shows a photograph of Blinks in his later years, whereas Fig. 2 shows him in his early middle years at his algae incubation tanks at the Hopkins Marine Station.

\section{The 2006 symposium in California}

During the centennial celebration of the Botanical Society of America in Chico, California (August 1, 2006), a symposium honored Lawrence Rogers Blinks (1900-1989) and his critical research in plant ecophysiology, synthesis of information in reviews, editorship, and service to the plant research community, education and scientific institutions. Below is a tribute to his work in photosynthesis assessed by his colleagues, which does not fully address his appreciable contribution to algal ecophysiology and ion transport across the membranes of giant cells of algae. What follows is obtained partially from the information presented at the Symposium sponsored jointly by the Physiological and the Phycological sections of the Botanical Society of America, "A Tribute to L.R. Blinks," which included substantive

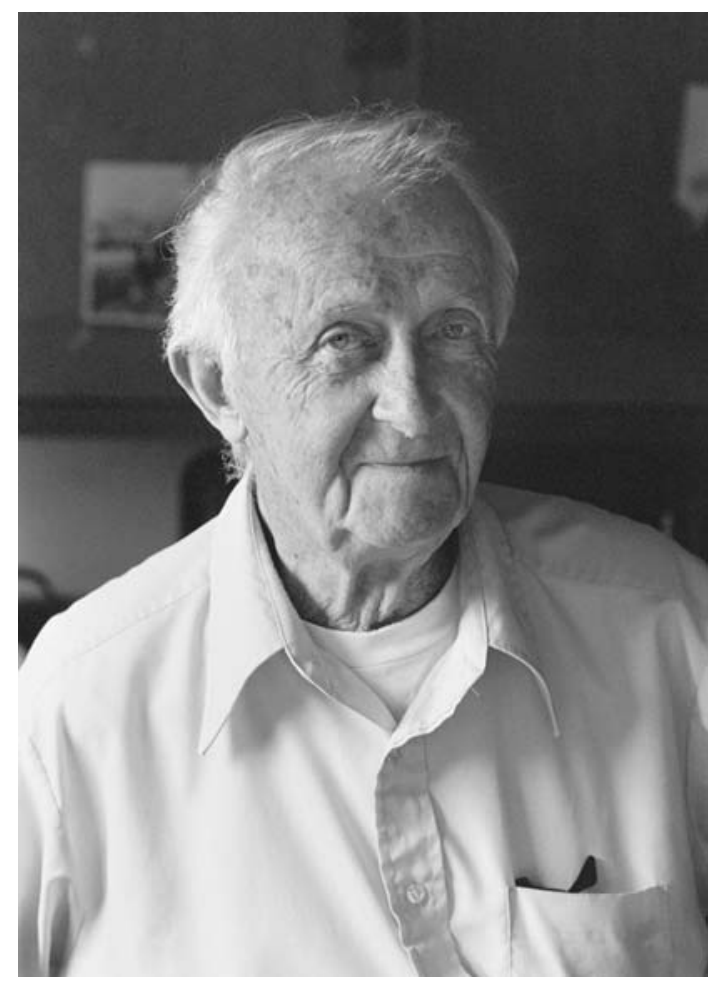

Fig. 1 Lawrence R. Blinks in his later years in his laboratory at the Hopkins Marine Station of Stanford University after his retirement from Stanford (Source: Library of the Hopkins Marine Station of Stanford University, Pacific Grove, CA)

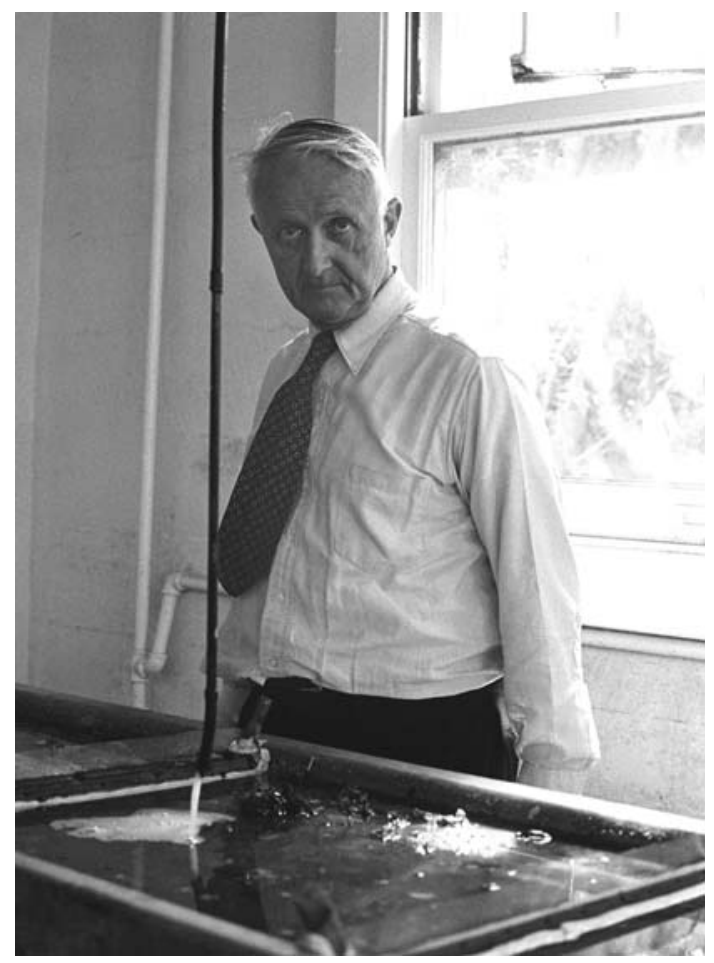

Fig. 2 Lawrence R. Blinks with his algae cultivation tanks at Hopkins Marine Station of Stanford University in Pacific Grove, California (Source: same as that for-Fig. 1) 
contributions (in alphabetical order) by John Blinks, Jack Dainty, Mary Jo Ryan Duncan, Richard Eppley, Francis Haxo, Nancy Nicholson, Barbara Pope, Cecilia Smith with Isabella Abbott, Anitra Thorhaug, and William Vidaver. This symposium was organized by one of us (A.T.) and M.J. Ryan Duncan. Included herein are also the opinions of authoritative reviews of photosynthesis research on Blinks by others (with their permission) who did not attend the celebration in California. The opinions expressed are those of the authors and the researchers quoted herein.

Although several photosynthesis publications of Lawrence R. Blinks are most frequently cited in photosynthesis reviews, his other investigations have also been continually cited and were of critical importance to early plant membrane transport physiology, marine phycology, and marine ecophysiology. Many investigators have felt that his major contributions to photosynthesis were those concerning accessory pigments, chromatic transients, and oxygen evolution during photosynthesis in marine algae. He published in photosynthesis mainly from 1946 to 1964, although he published articles on ion transport throughout his long professional life from 1926 into the 1980s. He also made important but less heralded contributions to the administration of the Hopkins Marine Station and to curricula in Phycology and Plant Physiology at Stanford University and the University of California at Santa Cruz. As mentioned in the Introduction, he provided general service to plant science during his vice presidency of the National Science Foundation, active membership in the US National Academy of Sciences and his editorial work for the Journal of General Physiology, the Annual Review of Plant Physiology, and several other journals as well as being President of the Society for General Physiology and Vice President for the American Association for the Advancement of Science.

\section{Early life and early investigations at Harvard University and Rockefeller Institute with Winthrop Osterhout and Jacques Loeb}

Lawrence Blinks was born in Michigan City, Indiana on April 22, 1900 to Walter Moulton Blinks and Ella Little Rogers Blinks. Shortly thereafter, his family moved to southern Michigan, where he attended public school and did well in science. After a year at Kalamazoo College, Kalamazoo, Michigan, he and his family moved to northern California. There, Blinks and his brother enrolled at Stanford for 2 years. His family then moved back to Michigan 2 years later, but Lawrence decided to enter Harvard University. (A relative of his mother's, John Rogers, had been president of Harvard (1682-1684) and many other family members were Harvard alumni.) After
Blinks finished his B.S. (1923), M.S. (1925), and Ph.D. (1926) with Prof. Winthrop Osterhout at Harvard in 1926, he went to the Bermuda Biological Station with Osterhout and was then invited to go to the Rockefeller Institute with Osterhout and Jacques Loeb. (Meanwhile, one night during the winter, 1 week after Loeb had arrived for a vacation in Bermuda, Jacques Loeb died at the Biological Station in the room that was just above Blinks's room.) Blinks had collaborated with Osterhout and Loeb in critical membrane transport work at the Rockefeller Institute and at the Bermuda Biological Station in the 1920s. This work included some of the earliest measurements of ion transport across cell membranes, of membrane conductance and transmembrane electric potential. The work formed the basis of our understanding of electrical activities in cells and was incorporated into animal research as well as plant physiology (Briggs et al. 1990). Blinks measured the fundamental parameters of the environmental variability of algal cells such as $\mathrm{pH}$, various concentrations of the major ionic salts, temperature, pressure, and light to elucidate the environmental variables acting on algal cells versus their electric characteristics (Blinks 1928, 1929, 1933, 1936a, b). He continued working with Osterhout into the early 1930s. At this time, the Great Depression hit the Rockefeller Institute's funding. For Blinks, a more serious problem was that Winthrop Osterhout suffered a massive heart attack in the winter of 1931. Blinks had previously been courted by Stanford University for a faculty position and been asked to teach at a summer session at Stanford. Upon Osterhout's illness, Stanford offered Blinks a position in 1931.

\section{Blinks moves to Stanford and begins photosynthesis research}

Blinks was an associate professor and eventually a full professor at Stanford University's main campus from 1931 to 1943. During 1943-1964, Blinks served as the Director of Stanford's Hopkins Marine Station (Pacific Grove). In 1955, he was elected a member of the National Academy of Sciences, USA. He left Stanford only five times: (1) for a year as Vice President (1954-1955) of the National Science Foundation under William McElroy's presidency; (2) for a sabbatical (1940-1941) ostensibly at the Carnegie Institutes' Tortugas Marine Laboratories (which was unavailable during World War II, so he stayed in Key West, Florida to study giant marine plant cell membranes); (3) another sabbatical in Stockholm, Sweden at the Nobel Institute; (4) a third sabbatical in 1949 in Cambridge, England on a Guggenheim award; and (5) at age 65, upon retirement from Stanford, Blinks also participated in the 
building of the Department of Biological Sciences at the University of California, Santa Cruz (1965-1973). Blinks returned to the Hopkins Marine Station as Professor Emeritus (1974-1989) where he continued to do physiological research mostly on oscillatory phenomena of giant algal cells versus a series of variables such as temperature, pH, and other stimuli (Blinks 1967, 1969, 1970, 1971; Blinks and Pope 1961), teach, and to participate in the life of the marine station until his death.

Blinks's research in photosynthesis followed several decades of highly productive original research on membranes and ion transport in giant algal cells; this work is still cited to this day by both membrane transport and algal physiology workers. We cite here references of those who cited Blinks both on photosynthesis $(\mathrm{P})$, algal physiology (AP) and on membrane transport (arranged chronologically, then alphabetically): Dainty 1962; Drost-Hansen and Thorhaug 1967; Katchalsky and Thorhaug 1974; Thorhaug 1974, 1978; Hodgkin 1976; Culver and Perry 1999 (AP); Subramaniam et al. 1999 (P); Wayne 1994; Wood et al. 1999; Beach et al. 2000 (P); Bouman et al. 2000 (P); Cornet and Albio 2000 (AP); Nishio 2000 (P). These findings "formed a basis for much of our understanding of electrical activity of cells, both plant and animal" (Briggs et al. 1990). Blinks's influence on membrane research is reflected in a 1985 unpublished letter by the Nobel laureate Alan Hodgkin to honor Blinks on his 85th birthday, "Finding Blinks's Nitella action potential in the Journal of General Physiology had an effect on my own thinking. I read all the works of Blinks from the 1920s-1940s." Indeed, A.L. Hodgkin referred to Blinks's work in his publications (Hodgkin 1951, 1976). Many consider Blinks's contributions to membrane transport work his most fundamental (Briggs et al. 1990).

\section{Blinks's early investigations on photosynthesis, as given by Francis Haxo to the authors, unpublished 2006 recollections}

In photosynthesis, Blinks's investigations began in the late 1930s on problems of ecological importance to a wide range of marine algal research at the molecular and biophysical level. Blinks began to focus on algal pigments, chromatic transients, and oxygen evolution in marine algae (Yocum and Blinks 1950, 1954, 1958).

According to Francis T. Haxo (Scripps Institution of Oceanography, Emeritus, pers. commun. 2006), "Blinks believed people were no longer interested in ion transport."

Reviewing the past, Francis Haxo (2008), from his unpublished notes written for this tribute, edited by one of us, A.T.) stated:
Research on the effectiveness of phycoerythrin as a photosynthetic pigment in red algae must have been on Blinks's mind for some time after his return to Stanford in 1931. Emerson and Lewis (1942) had provided for the first time evidence that light absorbed by phycocyanin in the blue-green alga Chroococcus was utilized as effectively as that absorbed directly by chlorophyll. Blinks had superior methodology at hand as early as 1937 in his rapid and sensitive method for measuring photosynthetic rates, the stationary bare platinum oxygen electrode (a technique that he was led to by his respiratory physiology colleague, J. Percy Baumberger, in substitution for the mercury electrode), and for spectral coverage, the plans, if not the components, for construction of a user-friendly, good-resolution monochromator, incorporating a linear dispersion replica grating of the Woods type. No less notable was the ready availability of an abundant and varied red algal flora (the richest on the Pacific Coast) including some especially suitable but fragile thin-bladed species, which allowed study of a wide range of pigment assemblages. All that was needed (to use Per Scholander's fishing analogy) 'was to hook a curious young mind on the professor's fly.' Blinks had offered the idea of a thesis on photosynthesis within red algae as a research project to William McElroy (later President of National Science foundation and Chancellor of University of California at San Diego), but McElroy began work on bioluminescence. Several years later, in 1944, under similar circumstances, I (F.T. Haxo), then a graduate student in photobiology with Arthur C. Giese and fresh from G.M. Smith's fascinating summer course on local marine algae, was readily drawn to Blinks's problem. These first studies suggested that not only was phycoerythrin a highly effective light-harvesting component for photosynthesis but that, surprisingly, half of the light absorbed by chlorophyll seemed to be inactive. The detailed action and absorption measurements needed to document this anomalous situation had to be postponed until I had completed the research for my doctoral dissertation on the identity and lightactivated biogenesis of the carotenoid pigments of the red bread mold Neurospora and its color mutants (a problem proposed by G. W. Beadle).

\section{Haxo continued:}

Thus in September 1946, I returned to Pacific Grove and began a year of intense research mostly buried in a dark room, rarely emerging to hear the friendly barking of the seals and to smell the output from the 
dwindling sardine factories along Monterey's Cannery Row. This erudite research somehow seemed much more important when Lawrence Blinks's presentation of the results in 1949 at the December meeting of the American Academy of Advances in Science (AAAS) in Chicago led to major newspaper science coverage with captions such as 'California Scientists Challenge Role Of Chlorophyll' an item even picked up by my home town newspaper in North Dakota. At that time we had no opportunity to explore further the unexpected finding that contrary to the results reported for Chroococcus (by then a lost culture) a significant pool of inactive chlorophyll also existed in a filamentous blue-green alga collected from nearby rocks. Later, a similar situation was also found for Oscillatoria by L.N.M. Duysens (see Duysens 1952) in his studies of energy transfer to chlorophyll $a$ and in my lab in the biliprotein-containing Cyanidium caldarium and in the cryptomonads, but to a lesser extent, attributable to their content of chlorophyll $c$ (Haxo and Fork 1959). Red algae were not so unique after all.

Shortly after I set up a lab in La Jolla, California, in the early 1950s, the interest of our labs converged in establishing the uniqueness of the phycoerythrin found in some species of the Bangiales, (now regarded as Class Bangiophyceae within Phylum Rhodophyte) a subgroup of the Rhodophyta, which by mutual agreement came to be called B-phycoerythrin (Airth and Blinks 1957). At La Jolla, we had found that the phycoerythrin fraction in the unicellular alga Porphyridium cruentum (which I had earlier learned to culture on enriched seawater media, thanks to a comment from E. G. Pringsheim) had the same blunted spectrum as that found in Porphyra (later Smithora) naiadum, one of the algae Blinks and I had studied. R. L. Airth in Blinks's lab had been using electrophoresis to purify its biliproteins and the existence of a protein complex was being considered. At La Jolla while renewing investigations on the phycobilins, little studied since R. Lemberg's days, Colm O'hEocha and I had found that column chromatography on tri-calcium phosphate, by the new method of Homer Scott Swingle and Arne Tiselius, was a powerful new tool for comparative studies of algal biliproteins, leading us, most notably, to establish the natural and wide occurrence of a fraction we called allophycocyanin, presuming it to be the same pigment observed by Lemberg in longstored material. O'hEocha introduced this methodology to Airth and Blinks during a summer study at the Hopkins Marine Station, leading them to abandon the idea of a complex, as we did for the name Pphycoerythrin we had given, in the interim, to this novel biliprotein. In 1960, R. Lemberg, then an immigrant to Australia, took great pleasure in showing me crystals of R-phycoerythrin preserved in ammonium sulfate on a slide that were in perfect condition after over 30 years.

Some of the simply displayed action spectra from Blinks, and my publication were widely duplicated in textbooks to illustrate spectral assimilation and pigment involvement in representative phototrophic systems of eukaryotes. They were also key to estimating spectral assimilation curves for photosynthesis with depth in the ocean by the principle algal groups, part of the photosynthesis exhibits that Melvin Calvin had organized as the US contribution to the science pavilion at the 1958 World Fair in Brussels, Belgium. The highlight of the US exhibit was a somewhat Rube Goldberg model of the CalvinBenson carbon cycle which upon illumination of an artificial leaf traced "lit up" carbon from carbon dioxide, through the various intermediates to sucrose which was ejected as a lump of sugar. Neither could match as crowd pleaser the model of Sputnik that the USSR had on display on the same floor. But in calculating these curves I failed to consider that in broad natural light fields, light absorbed by accessory pigments would have a marked enhancing effect on spectral performance at the ends of the spectrum, notably in phycoerythrin-rich red and blue-green algae (Haxo 1963).

In another interaction, David Fork, working with me (Haxo) for his $\mathrm{PhD}$, in his research at La Jolla (Fork 1960) and Blinks (1960a, b, c) quite independently found important new evidence bearing on the problem of "inactive chlorophyll" in red algae. As noted elsewhere (Briggs et al. 1990), our (Blinks's and my) earlier action spectrum studies of marine algae along with Blinks's new measurements on chromatic transients gave support to the idea of Robert Emerson that accessory pigments and chlorophyll are organized in special ways and that photosynthesis functions with two photosystems. Raw data for some of the results on chromatic transients (Blinks 1960a, b, c; Yocum and Blinks 1958) had already been shared with me by Blinks at the time I presented a review of accessory pigment function (Haxo 1960) at the 'First Annual Symposium on Comparative Biology of the Kaiser Foundation Research Institute" in 1959. There I described Fork's paired wavelength studies in Porphyra perforata 
showing that photosynthesis could be enhanced at both blue and red ends of the spectrum by simultaneously exciting mid spectrum absorption by the accessory biliprotein (see Haxo 1960, p. 356). (From Haxo 2008, unpublished manuscript.)

The single most cited (293 times) of Blinks's many photosynthesis papers is that by Haxo and Blinks (1950) on red algae, which has been recognized by a wide variety of photosynthesis investigators in more than 36 reviews on photosynthesis and more than 200 published articles (not including the many textbooks on plant physiology that quote him) (ISI Web of Knowledge). A series of important evaluations of this work and that of Blinks in photosynthesis are given below.

In summary, Blinks's first photosynthesis experiments included comparisons of many phyla of marine algae, as well as freshwater species, which he wisely knew had an array of chlorophyll as well as accessory pigment systems. Action potentials, monochromatic light in red, green, and blue region of the spectrum, and other techniques such as oxygen electrodes, which he had used since 1938 (Blinks and Skow 1938a, b) were of importance in the early experiments. Many of these investigations were done singly by Blinks himself. Other studies were done with colleagues such as F.T. Haxo, R.L. Airth, R.K. Skow, C.M. Lewis, C.M. Chambers, and C.S. Yocum (Blinks and Skow 1938a, b; Haxo and Blinks 1946, 1950; Blinks 1928, 1954a, b, 1957, 1959, 1960a, b, c; Airth and Blinks 1957, Blinks and Chambers 1958; Yocum and Blinks 1950, 1954, 1958). This early pioneering work was important because it led on to an understanding of the role of chlorophyll $a$ and phycobiliproteins in providing light energy to two separate light reactions, which are now known as photosystem I and photosystem II. This work was especially significant for cyanobacteria and red algae.

\section{Comments by a series of leading photosynthesis investigators of Blinks's contributions to photosynthesis}

We quote next a series of evaluations of Blinks's photosynthesis work by leading scientists in photosynthesis.

Bessel Kok and André Jagendorf (1963) wrote in the Preface of a book 'Photosynthetic Mechanisms of Green Plants', proceedings of a conference held at the 'Airlie' House in Warrenton, Virginia:

Blinks's report on chromatic transients brought the realization that photosynthesis in not 'color' blindand that different pigments might sensitize different photoprocesses. Soon followed the observation by the late Dr. Emerson of the enhancement effect in which lights of two different wavelengths proved to exert a greater effect if given simultaneously than if given individually.

Govindjee, the editor of this tribute, recalled an interesting statement that Bessel Kok made at the opening session at the Airlie House conference, while referring to the work of Emerson and of Blinks: "Every so often someone manages to remove another stone from the wall through which we all want to see, and the crowds tend to flock around the new peep hole."

\section{Jack Myers (1971) wrote:}

The phenomenon of chromatic transients was discovered by Lawrence Blinks (1957) in an experiment which is a model of raw curiosity. The output beam from his monochromator happened to give equal steady-state rates of net oxygen evolution of Porphyra at wavelengths 675 and $540 \mathrm{~nm}$. However, a rapid shift from 675 to $540 \mathrm{~nm}$ gave an up-transient (a transient increase in rate) while the shift [from] 540 to $675 \mathrm{~nm}$ gave a down-transient (a transient decrease in rate). Historically, the chromatic transients are [one of] the first of the phenomena which we now consider as demanding an explanation in terms of two separate photoreactions. It has become clear that the [Emerson] enhancement effect and the chromatic transients are causally related, that one is a steady-state and the other a time dependent manifestation of the same phenomena, and that they contain much the same kind of information. Hence both are embraced within the treatment given under the title of enhancement.

Govindjee and Krogmann (2004) commented.

During 1957-1959, Lawrence Blinks (1900-1989) observed transient changes in oxygen exchange when one wavelength of light is replaced by another (Blinks 1957; see review by Myers and French 1960). His preferred explanation of these effects was in terms of changes in respiration, but these are also explained by two light reactions (see Hill and Bendall 1960 and Duysens 1989), and later became important experimental evidence in favor of the hypothesis of two photosystems.

Larkum and Weyrauch (1977) further clarified the photosystem I and II in their experimental work on Griffithsia monilis from Athol Wharf in Sidney Harbor which was built on the pioneering work by Fork (1963a, b). In their results, Larkum and Weyrauch stated.

When action spectra are performed against a background light of various monochromatic wavelengths, it can be shown that chlorophyll $a$ increases in its 
light-harvesting activity. Nevertheless, light absorbed at a single wavelength $(487 \mathrm{~nm})$ by phycoerythrin (and possibly a carotenoid) still shows the highest photosynthetic activity. Fluorescence measurements at $77 \mathrm{~K}$ indicate that a chlorophyll $a$ fluorescence is small and that the amount of chlorophyll $a_{\mathrm{II}}(\mathrm{F} 693)$ is very low. A model is proposed in which the phycobilins, in phycobilisomes, pass on absorbed light energy to either photosystem, whereas light absorbed by chlorophyll $a$ is passed on mainly to photosystem I.

Larkum and Weyrauch (1977) also stated:

It is widely acknowledged that the modern era was introduced by the work of Haxo and Blinks (1950). The latter workers showed that in red algae (Rhodophyta) the biliproteins acted largely as the lightharvesting pigment replacing chlorophyll in this role. Much discussion followed as to the role of chlorophyll in red algae (Yocum and Blinks 1954; Brody and Emerson 1959). The question was largely resolved by the work of Duysens and Amesz (1962), which demonstrated the existence of two forms of chlorophyll $a$ in Porphyridium cruentum and suggested, along with other work of the time, the existence of two photosystems in series, each with its own species of chlorophyll $a$ and, in red algae, varying amounts of biliproteins contributing to each photosystem. As a result of these new hypotheses, action spectra were made against a background of monochromatic light. This work showed that at wavelengths of background light, absorbed by biliproteins, the participation of chlorophyll $a$ in the action spectra for red algae could be clearly discerned (Fork 1963a, b), a result anticipated by the work of Blinks (1960a, b, c) who observed similar effects but came to a different conclusion.

Albert Frenkel (1993, p. 106) in an autobiographical article observed:

Also, there were interesting talks with Blinks on the 'Chromatic Transients' in marine algae (Blinks 1960a, b, c). This discovery, in addition to Emerson's Enhancement Effects (Emerson et al. 1957), played an important role in the development of the concept of the two light reactions and two photosystems in oxygenic photosynthesis (reviewed by Duysens 1989).

Vernon and Avron (1965, p. 270) summarized the important discovery of Blinks with Haxo:

The action spectra of photosynthesis for a number of red algae were determined by Haxo and Blinks
(1950), who showed that red monochromatic light absorbed primarily by chlorophyll was much less effective for photosynthesis than light absorbed by the accessory pigment, phycoerythrin. [Govindjee (pers. commun.) reminded us that it is important to emphasize that Duysens (1952) had discovered that most of the chlorophyll $a$ molecules in red algae were inactive in transferring energy to fluorescent chlorophyll $a$, where phycobilins transferred energy with high efficiency to fluorescent chlorophyll $a$. Later, Duysens et al. (1961) proved the existence of two light reactions in red algae, where most of phycobilins were in Photosystem II and most of Chlorophyll $a$ in Photosystem I.] Emerson et al. (1957) had reinvestigated the red drop observed with [the green alga] Chlorella [Emerson and Lewis (1943)] and reported the following significant results: (a) monochromatic light absorbed on the long wavelength side of the red absorption band of chlorophyll in vivo was less efficient in promoting photosynthesis (the red drop...); and (b) adding a weak background of green light produced higher quantum efficiencies which were maintained further into the red region. The concept of enhancement and the two light reactions arose from these experiments.

In the same review, p. 209, Vernon and Avron also said that part of "the evidence for two pigment systems in photosynthesis was Blinks's Ulva work (Haxo and Blinks 1950; Yocum and Blinks 1950, 1954; Blinks 1957, 1959) which caused a pulse of oxygen evolution, the height and duration of which depend on the history of the cell."

In a review on phycobilins and phycobilisomes, Tandeau de Marsac (2003) stated:

About 60 years later, however, the major role of the different phycobilins from red algae and cyanobacteria in light-harvesting for photosynthesis was largely confirmed and quantitatively established by several groups (Emerson and Lewis 1942; Blinks 1954a, b; Brody and Emerson 1959; Lemasson et al. 1973).

Tandeau de Marsac also mentioned:

The discovery of two spectrally slightly different phycoerythrins in primitive red algae of the order of Bangiales (Bangiophyceae) B-phycoerythrin (Airth and Blinks 1956) and the b-phycoerythrin (Gantt and Lipschultz 1974); the nomenclature of " $R$ " for red algae was no longer valid. Consequently, these prefixes no more refer to the type of source organisms but denote their specific spectral characteristics.

In reevaluating Blinks's contributions, Raven and Giraud-Bascoe (2001, p. 946) concluded: 
The second investigation of the Emerson [Enhancement] effect (Emerson et al. 1957; Emerson and Chalmers 1958)... was 'found' in the work of Blinks (1957, 1960a, b) on chromatic transients, involving sequential rather than simultaneous supply of the irradiation of different wavelengths to marine macroalgae. Blinks was forced to use sequential rather than simultaneous irradiations because he had used only one monochromator. However, Blinks's approach allowed him to confirm that enhancement did not necessarily involve simultaneous irradiation and so involved interaction between the different wavelengths at the level of chemical products of photochemistry rather than at the level of excitation energy or photochemistry.

According to Govindjee (pers. commun.), Emerson et al. (1957) used a shaking vessel, and the two light beams he used were also absorbed by the cells with some time delay; thus, they were also not quite 'simultaneous'. Further, the two light effect was clearly shown to be not in respiration, as Blinks had thought: (a) R. Govindjee et al. (1960) discovered a two-light effect in a benzoquinone Hill reaction in Chlorella cells, where benzoquinone had inhibited respiration; (b) Govindjee et al. (1963) showed, using mass spectroscopy, that the effect was in photosynthesis, not in respiration. Later, Govindjee and R. Govindjee (1965) thoroughly examined the Blinks (and Emerson) Effects with red and green pulses in red algae and provided further details on the differences between the order of presenting the two light pulses, and on the influence of nonlinear "light curves" on quantitative values of the enhancement effect. Larkum and Weyrauch (1977) elucidated why the Chlorophyll $a$ was inactive in red algae (and cyanobacteria) showing that most of the Chlorophyll $a$ is attached to Photosystem I and is not in communication with Photosystem II (whereas phycobiliprotein is connected to both the photosystems).

\section{Blinks's contribution to whole organism response to environmental stimuli}

In our view, Blinks's most outstanding overall attribute was his respect for the whole organism interacting with its environment and his seamless integration of knowledge from the molecular realm to the level of the whole organism. Blinks's deep understanding of the environment of algae may be why the present generation of ecologically oriented phycologists continue to appreciate his work (Fu and Bell 2003; Morand and Briand 1996; Pelletreau and Muller-Parker 2002; Sasaki et al. 2005; Stenck and Dethier 1994; Vadas et al. 2004; Yano et al. 2004). A central part of his focus on the essence of critical problems was his profound understanding of the ecological context of the species and their ecosystems in which he worked. For example, it is clear that since red light is damped out of oceanic water within the first few meters, that red algae must generally live with green and blue light sources, so, of course, he tried monochromatic color lights of the ocean such as green and blue versus surface red light for those living in very shallow waters (almost none are intertidal). Another example is the measurement by Blinks (1963) on the effects of changes in $\mathrm{pH}$ on photosynthesis by intertidal algae. As pointed out by John Raven (personal communication), this field is now a very popular field of research due to increasing interest in ocean acidification. His specimens were also fresher, thus providing clearer results as the healthiest of specimens frequently demonstrate, especially in the highly fragile red algae, which are so difficult to culture in the laboratory. During his many years at the Hopkins Marine Station, he was in the field almost daily, noting events and collecting algae. He chose to work and live at Pacific Grove because the field was immediately at hand literally in the back yard and surrounding him on three sides on the Pacific Grove-Carmel Peninsula. In his tribute to Blinks, Richard Eppley (2006) remembered him at the end of classes playing a giant kelp as a trumpet. We remember him clearly in the field during his mid-60s through his early 80 s as very vigorously and enthusiastically collecting algae. He even had secret places in Hawaii and Florida where he obtained his giant cells. In his teaching courses, he demonstrated and transmitted his profound knowledge of how the organism functioned in its natural environment to his students. From this organismal and ecophysiological basis, he was able to delineate essential questions and then to develop procedures and methodologies to study them.

\section{Blinks's qualities as a scientist, a summary}

One of the fundamental characteristics of Lawrence Blinks was his unquenchable curiosity about the way in which plants responded to various stimuli. All former colleagues and students recalled their shared moments of discovery of new algal responses. Such moments were highly elating to him and his colleagues; in fact a bottle of wine from his own vineyard was often opened at the moment of a new discovery as Barbara Pope had described when the oscillatory phenomena was discovered, whereas normally his manner was very self-effacing. In the early years (19201944), when his focus was directed toward membrane transport in giant algal cells, their ion permeability, and their transport system, he made a series of discoveries about the effects of light, $\mathrm{pH}$, pressure, and various 
electrolytes and solutes on the ion and water transport in Valonia, Halicystis, Derbesia, Boergesenia, and Nitella, among other species (see e.g., Blinks and Pope 1961). In 1938 , he turned a portion of his research attention to algal photosynthetic responses and the chromatic transients. In his later years (1967-1989), this consuming thirst for biological understanding led him to investigate the oscillatory phenomena in giant algal cells in response to light as well as a series of other stimuli and to return to experimenting with giant cells (see e.g., Blinks and Pope 1961; Blinks 1971). In these oscillatory phenomena, a plant's variability for its response to a stimulus was measured-usually via its bioelectric potential with a strip chart recorder versus time. The stimulus would be applied after the baseline potential for the specimen was established. Then, the specimen would begin an oscillation, which was clearly recorded on a strip chart recorder as a function of time. Some oscillations lasted only several seconds, others went on many minutes. The relationship between stimulus and magnitude and length of response was the focus. These experiments required detailed data and reproducibility. Blinks examined a series of stimuli and responses which caused such oscillations and attempted to explain this very complex phenomenon which can be found in artificial membranes (Selegny 1976). Had Blinks been blessed with a bit more time, he no doubt would have synthesized the data he was working on at the time of his death with an astute hypothesis of the underlying causal factors. An unanswered question is why he did not try combining the membrane techniques in the giant green algae that he had charted with the photosynthetic phenomena once he had tried light as a stimulant on bioelectric potential (Airth and Blinks 1957; Blinks and Chambers 1958; Blinks 1971)? Why did he not try blue and red light on the membranes and the other effects as stimulants for the membrane bioelectric effects?

Francis Haxo (2006; unpublished) recalled:

During the maiden voyage of the RV Alpha Helix to the Great Barrier Reef in 1966, Blinks joined the group of photobiologists and biochemists we had assembled to study photosynthesis and pigments of symbiotic associations in corals and giant clams. Kazuo Shibata arranged to have the Shimadzu Co. in Japan ship his newly designed but bulky Multipurpose Spectrophotometer to Brisbane, Australia. After loading it to our laboratories, it permitted novel studies with Per Halldal, Shirley Jeffrey and I (see Halldal 1968; Shibata 1969) such as spectral light absorption and photosynthesis by the submerged green layer of corals, the occurrence of a unique phycoerythrin in the bloom of the cyanobacterium Trichodesmium and, in symbiotic dinoflagellates of corals, energy transfer from peridinin to chlorophyll $a$ in a protein complex (later named PCP). By contrast, Blinks obtained all the accurate data he needed with the simple Heathkit potentiometer/recorder he had assembled and brought along in a suitcase as he renewed his interest in bioelectric phenomena of giant single-celled algae, in this case Boergesenia, available to him for the first time in this tropical Pacific location. He located and collected his own supply of algae and buried himself for hours on end in an air-conditioned inner laboratory.

This recollection demonstrates Blinks's fundamental challenge with the membrane phenomena, when he had an opportunity to look further at a variety of photosynthesis opportunities, but chose membranes. Isabella Abbott at the tribute to Blinks at Chico, California, recalled Blinks going back to the South Pacific to collect giant algal cells. One of us (A.T.) went on a series of Valonia-collecting trips with him in the 1960s-1970s, primarily in the Florida Keys, one of his favorite haunts where he knew many secret Valonia places as did A.T., trading collecting and transporting secrets. Subsequently, A.T. would bring him the treasured Valonia from around the Western Hemisphere (of several species) for his living collection at Pacific Grove, with which he regularly worked as she migrated back and forth from Florida and the Caribbean to Berkeley, California.

He was almost into his 90s, still working in retirement alone in his labs with the giant algal cells, entertaining his scientific visitors and former students with a walk on the beach to see his cherished algae in their habitat. Francis Haxo (2006; unpublished) recalled back in California some years after 1966: "I was to have my last vision of Blinks in a corner of a very crowded Hopkins Marine Station seated at a small desk with comparable instrumentation, deeply engrossed in the electric responses of an impaled Halicystis."

Another outstanding characteristic was his bold approach to finding answers and methods to explore the essence of algal physiological problems. He was little influenced by questions capturing the imagination of the general scientific community or the "idea of the moment" with granting agencies, but rather concentrated on those fundamental questions of plant (algal) ecophysiology that in his experience and wisdom he deemed important. His approach to his work was always mediated by the state of instrumentation. If an instrument wasn't available, he invented it. From the 1920 s to 1980 s, instrumentation was in rapid flux. He had a superior ability to invent or retool instruments that were necessary to solve his problems. Examples are his oxygen electrodes, which led the way to studies of chromatic transients (Blinks and Skow 1938a, b) and a high pressure 
machine for measuring algal responses under high barometric pressure He encouraged William Vidaver, then a $\mathrm{Ph}$. D student with him, to assemble and use a 'high pressure' apparatus to work on algae (Vidaver 1961). Blinks's skill with instrumentation, that had begun in the Osterhout's laboratories at Harvard and Rockefeller Institute, was an important part of his progress in unraveling mysteries of algal physiology.

\section{Blinks's contributions to editorial and synthetic aspects of algal physiology}

Blinks was prolific in his publications on both membrane and photosynthetic responses and published extensively in the Journal of General Physiology early in his career, then in the Proceedings of the National Academy of Sciences (USA) toward the end of his career. Most of his publications were thus widely disseminated. His least-recognized contribution was as an evaluator of scientific research. His critical influence was seen in the editorial capacity he held for a series of journals such as the Journal of General Physiology where he replaced Winthrop Osterhout, who was in failing health, to become co-editor with Alfred Mirsky in 1951 and continued for decades on the expanded editorial board after 1956 (Andersen 1965) and Annual Reviews of Plant Physiology, where he served as editor for a year (about 1956) and edited the 5th, 7th, and 10th editions of these annual reviews. He was then on the editorial board for many years. He also served as a contributing editor to Plant Physiology, Journal of Phycology, Botanica Marina, and others. Evaluation of plant physiology (including algal physiology) for these journals was an almost invisible portion of his contribution. He also served by editing publications of colleagues and students; they knew him as an excellent editor and synthesizer of large fields of information, wherein he was frequently asked to write summary, or review, articles.

\section{Blinks's students, teaching methods, and research rapport}

The legacy of Blinks includes his stellar support of investigations of a variety of physiological algal problems by students and colleagues. All the investigators at the symposium of the Botanical Society in 2006 commented on their direct benefits from his wisdom and critical thinking about their chosen problems. Also, his ability to treat students as scientific colleagues and to encourage independent critical thinking in discussions and formulating hypotheses for their projects was strongly praised by all those who studied with him in classroom and laboratory.
William McElroy (1918-1999, former President of the National Science Foundation and Chancellor of the University of California) recounted that the respect and dignity with which he was treated in Blinks's laboratory as a student was fundamental to his future in science in bioluminescence research and as an educator (McElroy 1976). Conversely, Blinks distinctly disliked his year as Vice President at the National Science Foundation in charge of funding for life sciences and was extremely glad to get back to his research bench at Hopkins. The role that Blinks had in directly helping students to become scientists and in supporting them in writing publishable scientific papers was exemplary. He almost always modestly declined to coauthor, saying "You did the work, so you deserve the publication," a facet which has not been adequately appreciated. He was a self-effacing personality who did not seek or demand awards or recognition. His dislike (probably emanating from his modesty) of presenting scientific papers and taking the time away from important scientific pursuits to travel to scientific meetings also created a lack of knowledge of his work by the US and international plant physiologists, especially in the late 1950s onward, to the detriment of the world's subsequent algal physiologists. In his retirement years, the new generation of plant physiologists and phycologists did not benefit from his wisdom and research because he published little from 1968 to 1989 and participated in national or international meetings even more infrequently.

\section{The "Golden Days of Biology": aspects of the life of a biologist from the 1920s to early 1960s}

Blinks lived his early research life in a rarified scientific environment surrounded by men of genius, by great discoveries, and breakthroughs in plant science including molecular biology. Beatrice Sweeney (1987) called it the "Golden Age of Biology," wherein the scientific community was small, most knew one another, interacted frequently, and shared ideas. It was in this early setting that Blinks made his critical inroads into the behavior of ion transport across various algal membranes. He also lived a fortunate life in terms of when and where he chose to do his science, from the four national academy members who taught him undergraduate biology at Stanford, the laboratories of Osterhout at Harvard and Jacques Loeb at Rockefeller, to the 10 years as a young associate and full professor at Stanford with George Beadle, V.C. Twitty, D.M. Whitaker, C.V. Taylor, and Arthur Giese, and the Bay area photosynthesis and other scientists of the 1930s1950s, C. Stacy French, Dennis Hoagland, Martin Kamen, Sam Ruben, Robert Emerson, and Louis N.M. Duysens (who visited Stanford from the Netherlands), and finally 
the Hopkins Marine Station group (Cornelis B. Van Neil, Baas Becking, Daniel Mazia, and Don and Isabella Abbott). Thus, Blinks indeed lived in a rarified environment of research breakthroughs and keen minds. Through 70 years of research, he continued to make important contributions. Appendix 1 gives a partial list of his students and research colleagues.

Acknowledgments We thank Drs. Mary Jo Ryan Duncan, Beth Hazen, and Kathleen Coffee for editorial assistance. Also thanked for evaluations are Richard Eppley, Francis Haxo, William Vidaver, and John Blinks and other participants at the symposium (A Tribute to L.R. Blinks at the Botanical Society of America annual meeting, July 29-Aug 3, 2006, Chico, California), including the speakers Isabella Abbott, Cecilia Smith, Nancy Nicholson, and Mary Jo Ryan Duncan. Hopkins Marine Station is thanked for support, information and photos of L.R. Blinks. We also thank the Botanical Society of America executive board, particularly the Phycological Section, Martha Cooke, and the Physiological Section for support of this Symposium at California State University, Chico, August 2006. We thank Govindjee for inviting us to write this tribute, for his many suggestions to improve our manuscript, and for accepting it and submitting it to the typesetters.

\section{Appendix 1}

Partial list of Blinks's students and research colleagues (1920-1975)

Students: R.D. Rhodes, 1938; M.L. Darsie, 1939; P.M. Brooks, 1943; J.D. Anderson, 1949; D.M. Chambers, 1951; C.S. Yocum, 1951; L.H. Carpelan, 1953; F.D.H. MacDonald, 1954; R.L. Airth, 1955; A. Gibor, 1955; R.W. Eppley, 1957; B.M. Pope, 1963; W. Vidaver, 1963; L.K. Smith, 1968; A. Thorhaug, 1969.

Coworkers (Chronologically): Winthrop J.V. Osterhout; Jacques Loeb; A.G. Jacques; Anne Hof Blinks; R.D. Rhodes; M.L. Darsie R.K. Skow; R.L. Airth; G.M. Smith; C.S. Yocum; C.M. Lewis; J.H. McClendon; C.D. Pease; J.P. Nielsen; B.A. Fry; J.L. Peel; D. Saps; M.J. Pickett; D.I. Arnon; V.C. Twitty; D. Whittaker; H. Gaffron; F.T. Haxo; R. Eppley; W. Vidaver; R. F. Jones; D.V. Givan; C.M. Lewis; Barbara Pope; G.A. McCallem; A. Thorhaug.

\section{References}

Airth RL, Blinks LR (1956) A new phycoerythrin from Porphyra naiadum. Biol Bull 111:321-327

Airth RL, Blinks LR (1957) Properties of phycobilins from Porphyra naiadum. J Gen Physiol 41:77-90

Andersen OS (1965) The history of the Journal of General Physiology. J Gen Physiol 125:3-12

Beach KS, Smith CM, Okano R (2000) Experimental analysis of rhodophyte photoacclimation to PAR and UV-radiation using in vivo absorbance spectroscopy. Bot Mar 43:525-536
Blinks LR (1928) High and low frequency measurements with Laminaria. Science 68:235

Blinks LR (1929) Protoplasmic potentials in Halicystis. J Gen Physiol 13:223-229

Blinks LR (1933) Protoplasmic potentials in Halicystis III. The effects of ammonia. J Gen Physiol 17:109-128

Blinks LR (1936a) The polarization capacity and resistance of Valonia. J Gen Physiol 19:673-691

Blinks LR (1936b) The effects of current flow on Bioelectric potential. 1. Valonia. J Gen Physiol 19:633-672

Blinks LR (1954a) The photosynthetic function of pigments other than chlorophyll. Annu Rev Plant Physiol 5:93-114

Blinks LR (1954b) The role of accessory pigments in photosynthesis. Symposium on autotrophic micro-organisms. Cambridge at the University Press, Cambridge

Blinks LR (1957) Chromatic transient in photosynthesis of red algae. In: Gaffron H, Brown AH, French CS, Livingston R, Rabinowitch EI, Bl Strehler, Tolbert NE (eds) Research in photosynthesis. Interscience Publishers, New York, pp 444-449

Blinks LR (1959) Chromatic transients in the photosynthesis of a green alga. Plant Physiol 34:200-203

Blinks LR (1960a) Action spectra of chromatic transients and the Emerson effect in marine algae. Proc Natl Acad Sci USA 46:327-333

Blinks LR (1960b) Relation of photosynthetic transients to respiration. Science 131:1316

Blinks LR (1960c) Chromatic transients in the photosynthesis of green, brown, and red algae. In: Allen MB (ed) Comparative biochemistry of photoreactive systems. Academic Press, New York, pp 329-341

Blinks LR (1963) The effect of pH upon the photosynthesis of littoral marine algae. Protoplasma 57:126-136

Blinks LR (1967) Bioelectric properties of Boergesenia forbesii. Science 3774:535

Blinks LR (1969) Effect of protoplasmic acidity and of light on bioelectric potential of Valonia and Boergesenia. Proc Natl Acad Sci USA 63:223-224

Blinks LR (1970) Reversal of bioelectric potential of Valonia and Boergesenia by mild oxidants. Proc Natl Acad Sci USA 66:240 242

Blinks LR (1971) Interrelated effects of $\mathrm{pH}$, light and potassium on bioelectric potential of marine algae Halicyctis-(Derbesia)Osterhoutii. Proc Natl Acad Sci USA 68:1389-1390

Blinks LR, Airth RL (1957) Electroosmosis in Nitella. J Gen Physiol 41:383-396

Blinks LR, Chambers DM (1958) Effect of light on the biolelectric potential of Nitella. Science 128:1143-1145

Blinks LR, Pope BM (1961) Rhythmic oscillations of the potential of Halicystis. Science 134:142-145

Blinks LR, Skow RK (1938a) The time course of photosynthesis as shown by a rapid electrode method for oxygen. Proc Natl Acad Sci USA 24:420-427

Blinks LR, Skow RK (1938b) The time course of photosynthesis as shown by the glass electrode with anomalies in the acidity changes. Proc Natl Acad Sci USA 24:413-419

Bouman HA, Pratt T, Kraay GW, Sathyenranathy S, Irwin BD (2000) Bio-optical properties of the subtropical North Atlantic. II. Relevance to models of primary production. Mar Ecol Prog Ser 200:19-34

Briggs W, Giese A, Epel D (1990) Stanford Univ. Memorial Resolution: L. R. Blinks unpublished. Available upon request from the Library of the Hopkins Marine Station of Stanford University, Pacific Grove, CA

Brody M, Emerson R (1959) Quantum yield of photosynthesis in Porphyridium cruentum and the role of chlorophyll A in photosynthesis of red algae. J Gen Physiol 43:251-264 
Cornet JF, Albio J (2000) Modeling photoherotrophic growth kinetics of Rhodospirillum rubrum in rectangular photobioreactors. Biotechnol Prog 16:199-207

Culver ME, Perry MJ (1999) The response of photosynthetic absorption coefficients to irradiance in culture and in tidally mixed estuarine waters. Limn Ocean 44:24-36

Dainty J (1962) Ion potentials and electrical transport in plant cells. Annu Rev Plant Physiol Mol Biol 13:379-401

Drost-Hansen W, Thorhaug A (1967) Temperature effects in membrane phenomenon. Nature 215:506-508

Duysens (1952) Transfer of excitation energy in photosynthesis. Doctoral thesis. State University, Utrecht, The Netherlands

Duysens LNM (1964) Photosynthesis. Prog Biophys Mol Biol 14:1104

Duysens LNM (1989) The discovery of the two photosystems: a personal account. Photosynth Res 21:61-80

Duysens LNM, Amesz J (1962) Function and identification of two photochemical systems in photosynthesis. Biochim Biophys Acta 64:243-260

Duysens LNM, Amesz J, Kamp BM (1961) Two photochemical systems in photosynthesis. Nature 190:510-511

Emerson R, Chalmers RV (1958) Speculations concerning the function and phylogenetic significance of the accessory pigments of algae. Phycol Soc News Bull 11:51-56

Emerson R, Lewis CM (1942) The photosynthetic efficiency of phycocyanin in Chroococcus and the problem of carotenoid participation in photosynthesis. J Gen Physiol 25:579-595

Emerson R, Lewis CM (1943) The dependence of the quantum yield of Chlorella photosynthesis on wavelength of light. Am J Bot 30:165-178

Emerson R, Rabinowitch E (1960) Red drop and role of auxiliary pigments in photosynthesis. Plant Physiol 35:477-485

Emerson R, Chalmers RV, Cederstrand CN (1957) Some factors influencing the long wave limit of photosynthesis. Proc Natl Acad Sci USA 43:133-143

Eppley R (2006) A tribute to Professor L. R. Blinks. In: A tribute to Lawrence R. Blinks: light, ions, and algae. Amer Bot Soc July 31, Davis CA. Botany 2006. American Botanical Society Botany 2006.\#34

Fork DC (1960) Studies on photosynthetic enhancement in relation to chlorophyll $a$ activity and accessory pigment function. $\mathrm{PhD}$ dissertation, University of California, Berkeley

Fork DC (1963a) Observations on the function of chlorophyll a and accessory pigments in photosynthesis, pp 352-361. In: Photosynthetic Mechanisms of Green Plants (B. Kok, Chairman; A.T. Jagendorf, Organizer), Publication \#1145, National Academy of Sciences-National Research Council, Washington, DC

Fork DC (1963b) Action spectra of $\mathrm{O}_{2}$ evolution by chloroplasts with and without added substrate, for regeneration of $\mathrm{O}_{2}$ evolving ability by far-red, and for $\mathrm{O}_{2}$ uptake. Plant Physiol 38:323-332

Frenkel A (1993) Reflections. Photosynth Res 35:103-116

Fu FX, Bell PRF (2003) The effect of salinity on growth, pigmentation, $\mathrm{N}_{2}$ fixation and alkaline phosphatase activity of cultured Trichodesmium sp. Mar Ecol Prog Ser 257:69-76

Gantt E, Lipschultz CA (1974) Phycobilisomes of Porphyridium cruentum: pigment analysis. Biochemistry 13(14):2960-2966

Govindjee, Govindjee R (1965) Two different manifestations of enhancement in the photosynthesis of Porphyridium cruentum in flashing monochromatic light. Photochem Photobiol 4:401-415

Govindjee, Krogmann D (2004) Discoveries in oxygenic photosynthesis (1727-2003): a perspective: Dedicated to the memories of Martin Kamen (1920-2002) and William A. Arnold (19042001). Photosynth Res 80:15-57

Govindjee, Rabinowitch E (1960) Two forms of chlorophyll $a$ in vivo with distinct photochemical functions. Science 132:159-160
Govindjee, Owens OvH, Hoch G (1963) A mass spectroscopic study of the Emerson enhancement effect. Biochim Biophys Acta 75:281-284

Govindjee R, Thomas JB, Rabinowitch E (1960) Second Emerson effect in the Hill reaction of Chlorella cells with quinone as oxidant. Science 132:421

Halldal P (1968) Photosynthetic capacities and photosynthetic action spectra of endozoic algae of the massive coral Fava. Biol Bull 134:411-424

Haxo FT (1960) The wavelength dependence of photosynthesis and the role of accessory pigments. In: Allen MB (ed) Comparative biochemistry of photoreactive pigments. Academic Press, New York, pp 339-361

Haxo FT (1963) Some implications of recent studies on the role of accessory pigments to photosynthesis in submarine daylight. In: Tuthill LD (ed) Proceedings 10th Pacific Science Assoc. Bishop Museum Press, Honolulu, HA, p 159

Haxo FT (2006) Remembering LR Blinks. In: A Tribute to Lawrence R. Blinks, Light, Ions, Algae, Amer Bot Soc July 31, Davis Ca. Botany 2006 abstract \#38 in American Botanical Society web page under conferences

Haxo F, Blinks LR (1946) Photosynthetic action spectra in red algae. Amer J Bot 33:836-837

Haxo FT, Blinks LR (1950) Photosynthetic action spectra of marine algae. J Gen Physiol 33:389-422

Haxo FT, Fork DC (1959) Photosynthetically active accessory pigments of cryptomonads. Nature 184:1051-1052

Hill R, Bendall F (1960) Function of the cytochrome components in chloroplasts: a working hypothesis. Nature 186:136-137

Hodgkin AL (1951) The ionic basis of electrical activity. Biol Rev Camb Phil Soc 26:339-409

Hodgkin AL (1976) Chance and design in electrophysiologyInformal account of certain experiments on nerve carried out between 1932 and 1952. J Physiol 263:1-21

Katchalsky A, Thorhaug A (1974) The effects of temperature and thermoosmosis on the membrane system of Valonia ventrocosa. In: Nakamura K, Tsichiya Y (eds) Proc 7th Intnl Seaweed Symp. Tokyo, Japan, pp 1-12

Kok B, Jagendorf AT (1963) Preface In: Photosynthetic Mechanisms of Green Plants (B. Kok, Chairman; A.T. Jagendorf, Organizer), Publication\#1145, National Academy of Sciences, National Research Council, Washington, DC

Larkum AWD, Weyrauch SK (1977) Photosynthetic action spectra and light-harvesting in Griffithsia monilis (Rhodophyta). Photochem Photobiol 25:65-77

Lemasson C, Tandeaux De Marsac N, Cohen-Bazire G (1973) The role of allophycocyanin as a light-harvesting pigment in cyanobacteria. Proc Natl Acad Sci USA 70:3130-3133

McElroy WD (1976) From the precise to the ambiguous: light, banding and administration. Annu Rev Microbiol 30:1-20

Morand P, Briand X (1996) Excessive growth of macroalgae: a symptom of environmental disturbance. Bot Mar 39(6):491-516

Myers J (1971) Enhancement studies in photosynthesis. Annu Rev Plant Physiol 22:289-312

Myers J, French CS (1960) Evidences from action spectra for a specific participation of chlorophyll $b$ in photosynthesis. J Gen Physiol 43:723-736

Nishio JN (2000) Why are higher plants green? Evolution of higher plant photosynthesis pigment complement. Plant Cell Environ 23:539-548

Pelletreau KN, Muller-Parker G (2002) Sulfuric acid in the phaeophyte algae Desmarestia munda deters feeding by the sea urchin Stronglylocentrotus. Mar Biol 141:1-9

Raven JA, Giraud-Bascoe J (2001) Algal model systems and the elucidation of photosynthetic metabolism. J Phycol 37:943-950 
Sasaki H, Murakami A, Kawai H (2005) Seasonal stability of sulfuric acid accumulation in the Dictyotales (Phaeophyceae). Phycol Res 53:134-137

Selegny E (1976) Charged gels and membranes. Reidel Publishers, Dordrecht Netherlands

Shibata K (1969) Pigments and a UV-absorbing substance in corals and a blue-green alga living in the Great Barrier Reef. Plant Cell Physiol 10:325-335

Stenck RS, Dethier MN (1994) A functional group approach to the structure of algal-dominated communities. Oikos 69:476-498

Subramaniam A, Carpenter EK, Falkowski PG (1999) Bio-optical properties of the marine diazotrophic cyanobacteria Trichodesmium spp. I. Absorption and photosynthetic action spectra. Limn Oceanog 44:608-617

Sweeney BM (1987) Living in the golden age of Biology. Annu Rev Plant Physiol 38:1-10

Tandeau de Marsac N (2003) Phycobilins and phycoblisomes: the early observations. Photosynth Res 76:197-205

Thorhaug A (1974) The effect of temperature on the bioelectric potential of Valonia. Biochim Biophys Acta 225:151-158

Thorhaug A (1978) The effect of ouabain on the membrane of Valonia ventricosa. In: Selegny E (ed) Charged gels and membranes. Reidel Publishers, Dordrecht, Netherlands, pp 123-132

Vadas RL, Beal BF, Wright WA (2004) Biomass and productivity of red and green algae in the Cobscook Bay, Maine. Northeastern Naturlt 11:163-196
Vernon LP, Avron M (1965) Photosynthesis. Annu Rev Biochem 34:269-277

Vidaver W (1961) Algal photosynthesis at increased hydrostatic pressure. PhD dissertation. Hopkins Marine Station, Stanford University

Wayne R (1994) The excitability of plant cells-with a special emphasis on Characean internodal cells. Bot Rev 60:265-367

Wood AM, Lipsen M, Coobie P (1999) Fluorescence-based characterization of phycoerythrin-containing cynanobacteria communities in the Arabian Sea during Northeast and early southwest Monsoon (1994-1995). Deep-sea Res (Part II. Topical Studies in Oceans) 44:608-617

Yano T, Kamiya M, Murakami A, Sasaki H, Kawai M (2004) Morphological homoplasy in Japanese Plocamium species (Plocamiales, Rhodophyta) inferred from the Rubisco spacer sequence and intracellular acidity. J Phycol 43(4):383-393

Yocum CS, Blinks LR (1950) Photosynthetic quantum efficiencies of marine plants. Amer J Bot 37:683-692

Yocum CS, Blinks LR (1954) Photosynthetic efficiency marine plants. J Gen Physiol 38:1-16

Yocum CS, Blinks LR (1958) Light induced efficiency and pigment alteration in red algae. J Gen Physiol 41:1113-1117 